\title{
GREENING THE COMPANY'S FLEET - CASE STUDY OF AVTOSTEKLO LTD
}

\author{
Sandra Jež* \\ University of Maribor, Faculty of Logistics, Celje, Slovenia \\ Simona Šinko \\ University of Maribor, Faculty of Logistics, Celje, Slovenia \\ Matjaž Knez \\ University of Maribor, Faculty of Logistics, Celje, Slovenia \\ Matevž Obrecht \\ University of Maribor, Faculty of Logistics, Celje, Slovenia
}

Transport is responsible for $30 \%$ of all greenhouse gas emissions in Slovenia. Companies specialized in transport are challenged with seeking solutions how to reduce the pollution from their fleets on one side and reducing costs and increasing efficiency on the other. Greening the companies fleets is in rise all over the world. Beside reducing the costs the environmental issues such as carbon footprint is becoming more and more important for company's image. This paper is based on a research study of company Avtosteklo Ltd. Their primary activity is replacement of windscreens on vehicles which is often done at customers' homes or at their work places therefore company owns a fleet of 24 vehicles in 5 branches across Slovenia with huge amount of annually driven kilometres and consequently high carbon emissions. Calculations on their current fuel costs and released carbon dioxide were examined and cross-compared. Results showed that 78,9 tons of carbon dioxide is released in one month of their operations. Main goal of this paper is therefore to present possible positive effects of replacement of conventional vehicles with alternative ones. After reviewing and analysing several possibilities we have suggested replacement of conventional cars with electric ones as a long term solution since they don't release carbon dioxide in use phase. In order to identify the best solutions we have proposed also replacement of vehicles for long relations with vehicles on compressed natural gas. The study also showed significant impacts on reduction of fuel costs and vehicles maintaining.

Key words: Alternative fuel vehicles, Emissions, $\mathrm{CO}_{2}$, Green fleet, Sustainable transport, Avtosteklo Ltd.

\section{INTRODUCTION}

Environmental pollution is becoming one of the most important issues these days. Greenhouse gas emissions (GHG) are a factor which affects climate changes the most. In this paper we studied environmental pollution caused by company's fleets and present positive effects of greening the fleets in companies, which are identified as one of the main polluters. In Slovenia there is no systematic dealing with greening the fleets, while this is the established practice already in some countries. Companies are challenged by the issue how to reduce their impacts on environment and how to maintain effectiveness with as low costs as possible. According to the Slovenian environmental agency [01] main share of greenhouse gas emissions is carbon dioxide (further CO2) with $82 \%$, which is mainly the result of combustion of fossil fuels. In years between 1986 to 2007 greenhouse gas emissions grew by $175 \%$ and the growth increases annually by $1 \%$, which is alarming [01].

Companies worldwide are greening their fleets rapidly. Study [02] in United Kingdom compared fleet of fifty vehicles consisted of ten most popular conventional vehicles used in companies, with fleet of fifty vehicles consisted of ten most environmental friendly vehicles. Study revealed that investments in purchasing new cars would be returned in eighteen months and in the next four years the costs of the fleet would reached $60.000 £$ (approx.. 75.978 $€$ ) less than the fleet consisted of conventional vehicles. At the same time the emissions of $\mathrm{CO}_{2}$ would be decreased by $30 \%$. 
Main goals of greening the fleets are [3]: optimization of the use of vehicles in sense of the way of travel, fuel type, optimization of the routes, size of vehicles and increasing of the use of alternative fuels and sustainable technologies. Planning the greening of the fleet could be consisted of fleet management (fuel consumption monitoring, vehicle tracking, choosing the right size of vehicle, efficient purchasing and vehicle disposal), vehicle inspections and maintenance, use of environmentally friendly detergents and rational use of water, training and education of employees about efficient driving, policies which promote green practice or green policies of purchasing, use of hybrid vehicles (mix of gasolineelectricity or diesel-electricity) and use of alternative fuels such as biodiesel, ethanol and others.

In this paper a case study of greening the fleet in company Avtosteklo Ltd. based in Celje, Slovenia is presented. Company's main activity is replacement of windscreens on vehicles. The company is a market leader in Slovenia. Replacement of windscreens is performed in their branch offices, while more and more services are preformed out on the ground. Response time is usually one day. Company has five branch offices trough Slovenia: in Ljubljana, Celje, Maribor, Murska Sobota and Novo mesto. Company has the fleet of twenty-four vehicles for the purposes of services in the field and other company's activities. Vehicles are divided in three groups: service operational vehicles, replacement vehicles for customers and company cars. All vehicles are gasoline or diesel powered.

Main goals of this study were: the most accurate description of company's existing fleet, analysis of fuel and maintenance costs, analysis of environmental impacts and identification of three alternative vehicle replacements for each sector of the fleet, with hypothesize that it is possible to find solutions to decrease fuel costs and impacts on environment.

\section{METHODS}

The study began with literature and good practices overview. Based on the synthesis of accumulated knowledge, we formed our own approach. Participation and support of the top management and cooperation of employees is crucial for greening the company's fleet. Process of planning should include measures which are not too restrictive to the participants, but must also meet the all conditions for effectiveness of the fleet. Measures should be adapted to the company's activities and purpose of the fleet. The goal of decreasing $\mathrm{CO} 2$ should be defined by the company's objective [04]. However in this case it was not exactly defined. Most commonly used activities of greening the fleet are consisted of a) analysis of the fleet (list of all fleets vehicles; number of vehicles by type, fuel type and amount of fuel consumed), b) setting goals of decreasing fuel consumption and decreased $\mathrm{CO}_{2}$ (which should be realistic, measurable and reachable) and c) setting measures for achieving the goals (choosing most appropriate vehicles for company's purposes, eliminating unused vehicles, optimization of the driving cycle, regular maintenance an purchasing of the energy efficient alternative vehicles and electric vehicles) [05].

At the first stage the record of the fleet's current status was made. All 24 vehicles in the fleet were identified by the year of the manufacture, weight, engine power, Euro emission standard, type of engine, fuel consumption (lit/100 km) and CO2 emissions. Based on the gathered data the calculations have been made.

Total driven kilometres of each vehicle were calculated on driven kilometres in one month and in one day. This was needed for further determination of alternative vehicles. Calculations on average $\mathrm{CO}_{2}$ emissions for each vehicle were based on driven kilometres. Data were gathered for each vehicle group, so that we could have determined the group with the highest environmental impacts and the replacement with alternative vehicles could be done promptly.

Analysis of environmental impacts has been done with two most common used methods: Greenhouse Gas Protocol in Eco-indicator 99. Method GHG Protocol evaluates greenhouse gas emissions caused by fossil fuels. Method Eco-indicator measures impacts of vehicles on human health, quality of ecosystem and natural sources. Analysis of environmental impacts was made by computer program SimaPro, which enables gathering data from several different data bases. The same procedure was used to evaluate environmental impacts of chosen alternative vehicles and compared with conventional ones. Beside environmental impacts we were interested in savings on fuel costs and maintenance costs. Fuel costs were calculated based on driven kilometres and cost of fuel at the time the study was made [06]. 
After the analysis was made the solution proposals were identified. They were divided in two sections. First were short-term solutions, which can be implemented quickly in the meantime while the replacement can't be done. Company's fleet has been partly replaced with new vehicles few years ago. Vehicles are younger so it was assumed that company will not invest in new vehicles so soon. Calculations on savings of fuel costs were made for all four short term solutions, while on the catalyst solution there has been made also calculation on $\mathrm{CO}_{2}$ reduction.

As long term solutions the replacement of the whole fleet was proposed. Most suitable alternative vehicles were proposed for each sector because different segments of vehicles have different requirements. Analysis was made which appropriate alternatives exist on the EU market. We considered different criteria such as vehicle size, price and range. Proposed alternatives were selected from the range of identified alternatives with comparative analysis of different alternatives based on economic evaluation of return of investment (ROI) with special emphasis. Electric vehicles were most focused on, the gas-powered vehicle and hybrid vehicle were also proposed. Electric vehicles seemed most suitable option because of the focus on reduction of $\mathrm{CO}_{2}$ as they don't cause any emissions during the operating time. Gas-powered vehicles were chosen for the replacement of the vehicles with high number of driven kilometres, because the electric vehicles on the market have short battery range and interruptions of the work can't be met. Vehicles in the mobile unit sector were chosen based on size of the van and possibility of reconstruction of the back part, beside of environmental impact reduction. Company's demand was to keep the practical use of the existing vehicles, which are designed in the way that serves employees in the most suitable way. The whole spectre of electric light vehicles was searched. Replacement for two vehicles was found among gas-powered vehicles, since those two could serve to the highest amount of driven kilometres per day. Replacement vehicles were considered to be replaced by electric vehicles only, since the range was not a problem in this case. Smaller vehicles with lower price were searched. In the sector of company's business sector it was considered to replace them with alternative vehicles approximately the same class as the existing ones.

Technical data was gathered for each alternative vehicle. Electric vehicles were identified by size (height, width), highest speed, range and fuel/ power consumption, time of recharging battery, maximum load and price of the vehicle. Gaspowered vehicles were considered by capacity, highest speed, range, gas consumption per 100 kilometres, $\mathrm{CO} 2$ emissions and price. Hybrids were considered by use of energy as well by the use of gasoline. Chosen alternative vehicles were compared with all conventional vehicles in the existing fleet by fuel costs, maintenance costs and $\mathrm{CO} 2$ emissions. In this paper the most suitable replacement for each conventional vehicle from the fuel cost and $\mathrm{CO} 2$ emissions reduction perspective is presented.

\section{RESULTS}

The fleet consists from 24 vehicles in three different sectors by their purpose. First sector are mobile units (in total 9 vehicles -5 different models). All of them are light duty vehicles and they are used for service on field. There is converter for electricity from $12 \mathrm{~V}$ to $220 \mathrm{~V}$, so they can maintain their own electricity for the use of equipment needed to provide service [06]. Interior is equipped with shelves for tools and appliances and special holders for windscreens. The routes for each vehicle are carefully planned with the assistance of special computer program, which enables weekly and monthly planning of the routes. Drives are being optimized and planned by regions. Vehicles are not being in use all the time, since the activities are seasonal. Second sector are replacement vehicles which serve for the time when customers car is under repairmen in one of the branch offices. Most of the customers come to the branch office for the repair, but still they need a car, so they can use one of the replacement cars. There are eight vehicles for the customers. One branch offers also a bicycle as a replacement for the time of repair. The last sector includes business cars, which serve for the business activities. There are seven cars, but the study refers only to six, since the data for one car were not available. In Table 1 there are more details about company's fleet. 
Table 1: Presentation of existing fleet [07, 08, 09 and 10]

\begin{tabular}{|c|c|c|c|c|c|}
\hline Type/criterion & Year & $\begin{array}{l}\text { Euro } \\
\text { emission } \\
\text { standard }\end{array}$ & $\begin{array}{l}\text { Type of } \\
\text { engine }\end{array}$ & $\begin{array}{l}\text { Fuel consumption } \\
\text { per } 100 \mathrm{~km} \\
\text { combined }\end{array}$ & $\begin{array}{c}\mathrm{CO}_{2} \text { combined } \\
(\mathrm{g} / \mathrm{km})\end{array}$ \\
\hline \multicolumn{6}{|c|}{ MOBILE UNITS } \\
\hline Renault Master (2) & 2013 & EURO 5 & Diesel & 6.8 & 214 \\
\hline Renault Master (2) & 2008 & & Diesel & 6.9 & 176 \\
\hline Ford Transit Custom (2) & 2014 & EURO 5 & Diesel & 6.5 & 172 \\
\hline Ford Transit(2) & 2013 & EURO 5 & Diesel & 6,6 & 186 \\
\hline Renault Traffic & 2007 & & Diesel & 6.7 & 175 \\
\hline \multicolumn{6}{|c|}{ REPLACEMENT VEHICLES } \\
\hline Škoda Citigo (8) & 2014 & EURO 5 & Gasoline & 4.5 & 105 \\
\hline \multicolumn{6}{|c|}{ BUSINESS VEHICLES } \\
\hline Ford Focus 1.6 TDCI & 2014 & EURO 5 & Gasoline & 4.5 & 105 \\
\hline Ford C-Max & 2014 & EURO 6 & Diesel & 4.5 & 117 \\
\hline Škoda Octavia 1.6 TDI (2) & 2013 & EURO 5 & Diesel & 3.8 & 99 \\
\hline Volvo S80 & 2009 & EURO 4 & Diesel & 5.9 & 155 \\
\hline Volvo V70 & 2009 & EURO 4 & Diesel & 6.5 & 172 \\
\hline
\end{tabular}

Table 1 shows that all vehicles are fossil fuel powered. Replacement vehicles Škoda Citigo are gasoline powered while all the others are diesel powered. The oldest vehicle is Renault Traffic (2007); the newest vehicles were manufactured in 2014. The highest fuel consumption has Re- nault Master (2008) with 6.9 litters per 100 kilometres. The highest emissions are emitted from Renault Master (2013) $214 \mathrm{~g} / \mathrm{km}$. The amounts of emissions $\mathrm{CO} 2$ were calculated by the sectors and shown in the table below (Table 2 ).

Table 2: Kilometers driven and $\mathrm{CO}_{2}$ emmissions

\begin{tabular}{|l|c|c|c|c|c|c|}
\hline \multicolumn{1}{|c|}{ Sector } & $\mathbf{k m} / \mathbf{y e a r}$ & $\mathbf{k m} / \mathbf{m o n t h}$ & $\mathbf{k m} /$ day & $\mathbf{C O}_{\mathbf{2}}$ tons/year & $\mathbf{C O}_{\mathbf{2}}$ tons/month & $\mathbf{C O}_{\mathbf{2}}$ tons/day \\
\hline Mobile units & 227.589 & $29.964,18$ & 951,13 & 42,78 & 5,43 & 0,17 \\
\hline $\begin{array}{l}\text { Replacement } \\
\text { vehicles }\end{array}$ & 115.399 & $11.539,90$ & 379,41 & 12,12 & 1,21 & 0,04 \\
\hline $\begin{array}{l}\text { Business } \\
\text { vehicles }\end{array}$ & 446.336 & $41.741,97$ & $2.042,88$ & 61,35 & 5,56 & 0,19 \\
\hline Total & 789.324 & $83.246,05$ & $3.373,42$ & 116,25 & 12,20 & 0,40 \\
\hline
\end{tabular}

All together amount of driven kilometres was 789.324 per year. The highest amounts of released $\mathrm{CO}_{2}$ emissions were in business vehicles sector, which was the result of high age of vehicles and high amount of driven kilometres. Mobile units sector has a little bit lower amounts, which is result of not being in service all year. Sector replacement vehicles has as expected the lowest amounts which is the result of the use of vehicles by customers for short trips only. Figure 1 shows percentage values for each sector.

Data about kilometres driven per day were crucial for selection of alternative vehicles. Equation (1) is the base for calculating only average daily driven kilometres, but the data is relevant enough for the purpose of choosing the right alternative electric vehicles. Amounts of driven kilometres and $\mathrm{CO}_{2}$ emissions are shown in Table 3. Equation 1: Equation for calculation of average daily driven kilometers:

\section{Driven kilometres in time unit/ number of work days in time period =average number of kilometres driven per day}

Table [3] shows that the amounts of average driven kilometres per day are rather different by vehicles. In total company makes 3370.7 kilometres per day, which results in $396.59 \mathrm{~kg}$ of $\mathrm{CO}_{2}$ emissions. Highest amount of kilometres driven mobile units sector is 168.49 and the lowest 7.2 kilometres. 


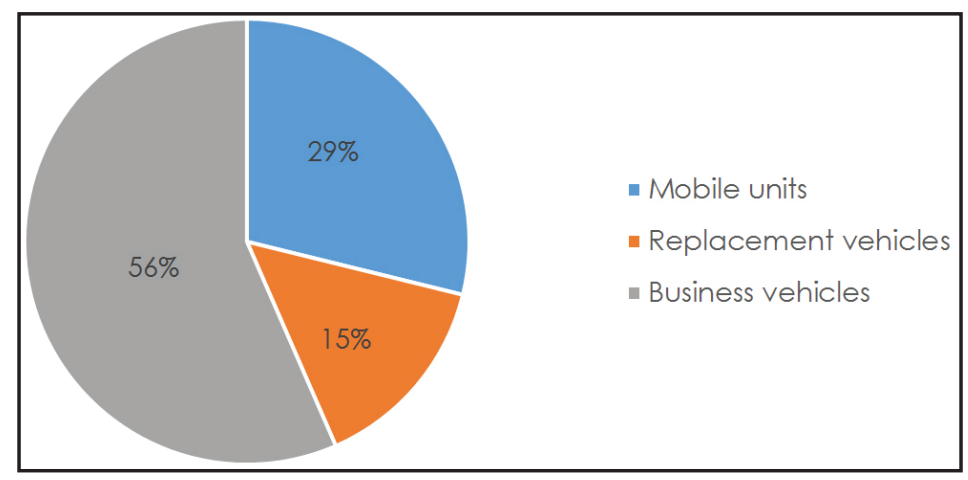

Figure 1: Shares for each sector (kilometers)

Table 3: Driven kilometers and $\mathrm{CO}_{2}$

\begin{tabular}{|c|c|c|}
\hline Vehicle & Average kilometres driven per day (km) & CO2 emissions per day $(\mathrm{kg})$ \\
\hline \multicolumn{3}{|c|}{ MOBILE UNITS } \\
\hline Renault Master 1 & 168.49 & 36.06 \\
\hline Renault Master 2 & 390 & 67.08 \\
\hline Ford Transit Custom 1 & 7.2 & 0.15 \\
\hline Ford Transit 1 & 69.03 & 12.84 \\
\hline Ford Transit Custom 2 & 14.23 & 2.45 \\
\hline Renault Traffic & 75.74 & 13.25 \\
\hline Renault Master 3 & 61.46 & 10.82 \\
\hline Renault Master 4 & 82.82 & 14.58 \\
\hline Ford Transit 2 & 79.44 & 13.90 \\
\hline \multicolumn{3}{|c|}{ REPLACEMENT VEHICLES } \\
\hline Škoda Citygo 1 & 59.14 & 6.21 \\
\hline Škoda Citygo 2 & 57.81 & 6.07 \\
\hline Škoda Citygo 3 & 38.04 & 3.99 \\
\hline Škoda Citygo 4 & 32.47 & 3.41 \\
\hline Škoda Citygo 5 & 52.65 & 5.53 \\
\hline Škoda Citygo 6 & 49.88 & 5.24 \\
\hline Škoda Citygo 7 & 32.50 & 3.41 \\
\hline Škoda Citygo 8 & 56.92 & 5.98 \\
\hline \multicolumn{3}{|c|}{ BUSINESS VEHICLES } \\
\hline Ford Focus & 131.40 & 15.37 \\
\hline Ford C-Max & 151.87 & 17.77 \\
\hline Škoda Octavia 1 & 197.12 & 19.51 \\
\hline Volvo S80 & 582.73 & 90.32 \\
\hline Volvo V70 & 164.38 & 28.27 \\
\hline Škoda Octavia 2 & 815.38 & 14.38 \\
\hline Total & 3370.7 & 396.59 \\
\hline
\end{tabular}

Replacement vehicles sector has highest amount 59.14 kilometres and lowest 32.47 kilometres. Vehicles with lowest amounts are from the branch office where as a replacement vehicle the bicycle is offered. One of the business vehicles makes 815.38 kilometres which is the highest amount in whole fleet. The lowest amount in business sector is 131.40 kilometres. Amount of driven kilometres was the base for calculations in fuel costs, which are presented in Figure 2. Fuel cost calculations were made on June $27^{\text {th }}, 2015$. When addressing fuel prices and return in investment in alternative fuelled vehicle, investor must be aware of fuel price volatility and possible changes in fuel prices during the vehicle's operational time. 


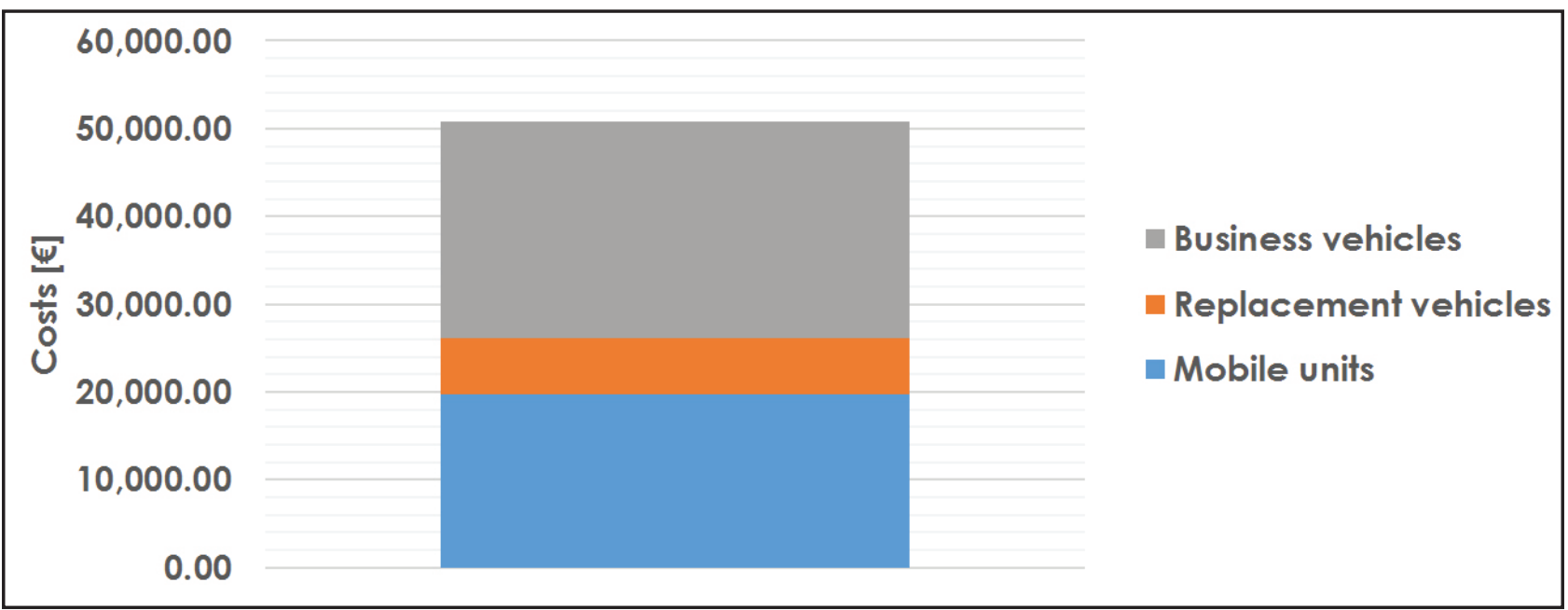

Figure 2: Fuel costs per year

Highest fuel cost was in business vehicle sector $24664.53 €$, followed by the sector of mobile units with $19770.94 €$. The lowest fuel costs were in replacement sector $6376.95 €$.

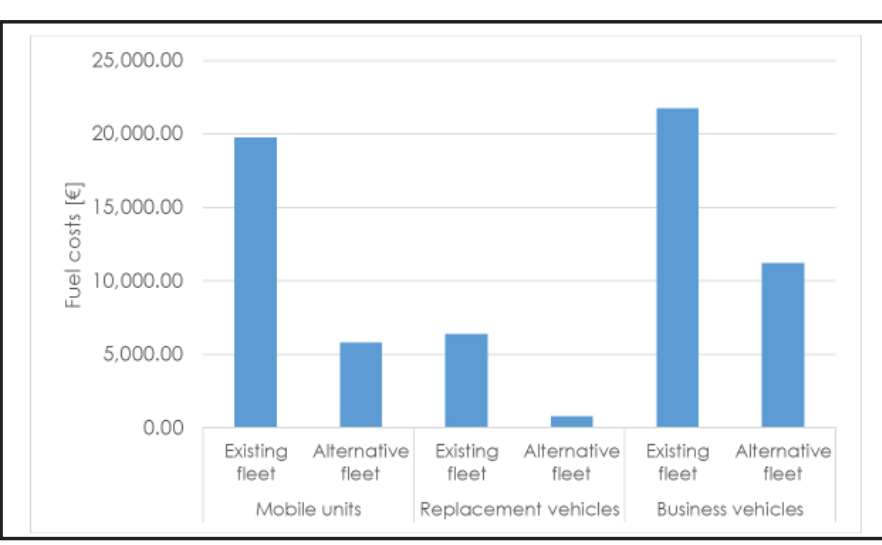

Figure 3: Comparison of costs existing fleet vs. alternative fleet

Total fuel costs were $50812.42 €$. Table [4] presents all selected vehicles with compared fuel costs (Figure [3]) and $\mathrm{CO}_{2}$ emissions (Figure [04]). Proposed alternative replacements in sector mobile units were: Nissan e-NV200, Renault Kangoo Maxi Z. E., Ford Transit Connect EV in Fiat Fiorino 1.4 8V Natural Power. Analysis and comparisons between existing fleet and selected proposals showed that Fiat Fiorino 1.4 8V Natural Power which uses natural gas as power, was the best choice for two vehicles. It was chosen because other alternative vehicles weren't suitable for this range. Fiat Fiorino has 300 kilometres of range which is more than enough for daily needs. Alternative vehicle to replace all other existing ones was Renault Kangoo Maxi Z . E with range 170 kilometres with fully charged battery; vehicle can be loaded with 800 kilograms.
Replacement vehicles best suited with alternatives VW e-up!, Renault Twizy 80 and Yogomo Ma4E. After further analysis and comparisons VW e-up! and Renault Twizy 80 were selected as the most appropriate for European market.

Two business vehicles would be replaced with alternatives Ford Focus Electric and Tesla model S. Ford Focus has highest speed $135 \mathrm{~km} / \mathrm{h}$, which is more than the highest speed limit in Slovenia. Range with fully charged battery is 135 kilometres. Advantage of this vehicle is that has quick charging battery that can be charged up to $80 \%$ in just 30 minutes. Tesla model $\mathrm{S}$ has $415 \mathrm{~km}$ range and is the best electric vehicle to buy in Slovenia (from the range perspective). We have chosen two hybrid vehicles, powered with gasoline and electricity. Lexus IS 300h has engine EURO 6 and can reach $200 \mathrm{~km} / \mathrm{h}$. This model has the lowest $\mathrm{CO}_{2}$ emissions among Lexus vehicles. VW Golf GTE is connecting hybrid, with range using electricity 50 kilometres, combined with full tank of gasoline the range is up to 939 kilometres. The last proposed alternative vehicle is Mercedes Benz B 200 NGD, which uses compressed natural gas as power. Beside gas-power there is also gasoline tank with 12 litters capacity. Range is 500 kilometres on natural gas only. Figure [3] shows comparison of fuel costs of existing fleet with selected alternatives. With selected alternatives fuel costs for mobile unit sector would be $5827.95 €$, which results in $70.5 \%$ savings. Fuel cost for business vehicles would be $11219.98 €$, which is $54.51 \%$ savings. In sector replacement vehicles the savings would be highest, $87.8 \%$, with fuel costs only $777.87 €$. Total replacement of existing fleet with alternative one would result in total $64,9 \%$ fuel cost savings. 
Table 4: Selected alternative vehicles

\begin{tabular}{|c|c|c|}
\hline Vehicle from existing fleet & Proposed alternative & Type of power \\
\hline \multicolumn{3}{|c|}{ MOBILE UNITS } \\
\hline $\begin{array}{l}\text { Renault Master 1; Ford } \\
\text { Transit Custom } 1\end{array}$ & $\begin{array}{c}\text { Fiat Fiorino } 1.48 \mathrm{~V} \text { Natural } \\
\text { Power }\end{array}$ & Natural gas \\
\hline $\begin{array}{l}\text { Ford Transit Custom 2; } \\
\text { Ford Transit 1; Renault } \\
\text { Traffic; Renault Master 2; } \\
\text { Renault Master 3; Renault } \\
\text { Master 4; Ford Transit } 2\end{array}$ & Renault Kangoo Maxi Z.E. & Electricity \\
\hline \multicolumn{3}{|c|}{ REPLACEMENT VEHICLES } \\
\hline $\begin{array}{l}\text { Vehicle 1; Vehicle 3; } \\
\text { Vehicle 5; Vehicle } 8\end{array}$ & VW e-up! & Electricity \\
\hline $\begin{array}{l}\text { Vehicle 2; Vehicle 4; } \\
\text { Vehicle 6; Vehicle } 7\end{array}$ & Renault Twizy 80 & Electricity \\
\hline \multicolumn{3}{|c|}{ BUSINESS VEHICLES } \\
\hline Ford Focus & Ford Focus Electric & Electricity \\
\hline Volvo S80 & Tesla model S & Electricity \\
\hline Volvo V70 & Lexus IS 300h & Hybrid (gasoline and electricity) \\
\hline $\begin{array}{l}\text { Škoda Octavia 1; Škoda } \\
\text { Octavia } 2\end{array}$ & VW Golf GTE & Hybrid (gasoline and electricity) \\
\hline Ford C-Max & Mercedes Benz B 200 & Natural gas \\
\hline
\end{tabular}

Figure [4] presents comparison of $\mathrm{CO}_{2}$ emissions for existing fleet and alternative one. With existing fleet company caused 116.25 tons $\mathrm{CO}_{2}$ in the time of measuring. With alternative vehicle fleet, consisting from almost electric vehicles, two gas vehicles and two hybrid vehicles, company would cause just 21.82 tons of $\mathrm{CO}_{2}$. This means $81.14 \%$ less $\mathrm{CO}_{2}$ emissions. At the end of study we compared environmental impact of the use of alternative vehicles, to verify if we choose environmental friendly vehicles. Table [5] represents results we got from program SimaPro and data base Ecoivent. We took into account the 100 000 kilometres, because this is the range, which is done in all three sectors in very short time. Results are in Eco indicators points $(\mathrm{Pt})$.

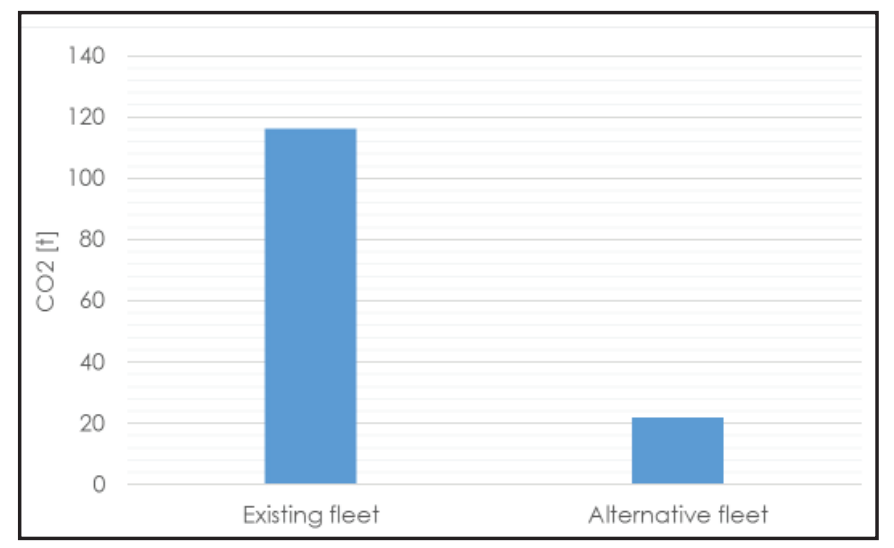

Figure 4: Comparison of $\mathrm{CO}_{2}$ emissions existing fleet $v s$. alternative fleet

Journal of Applied Engineering Science 15(2017)1, 413
Following vehicles were compared: vehicle with gasoline and vehicle with diesel engine were compared, both of them EURO 5 emission standard, which is most common standard in existing fleet; electric vehicle; gas powered vehicle and hybrid vehicle with $70 \%$ gasoline and $30 \%$ electricity power. Total environmental impacts is sum of impacts on human health, impacts on quality of ecosystem and impact on sources used to produce the vehicle. All compared vehicles with exception of electric vehicle, have the highest impact on human health. This is average $93.1 \%$ of total environmental impact. Lowest total environmental impacts has electric vehicle resulting in $374 \mathrm{Pt}$ and highest impact on sources $(58.2 \%$ of total impacts) which was expected since the production of electric vehicles is environmentally the most problematic. The gas powered vehicle has second lowest total environmental impacts and lowest impacts on sources. Highest total environmental impacts has vehicle with gasoline engine $863 \mathrm{Pt}$ and not diesel as expected.

\section{DISCCUSSION AND CONCLUSION}

Study confirmed the fact that fleets have huge impacts on environmental pollution. Amounts of $\mathrm{CO}_{2}$ are enormous because of high amount of driven kilometres. Alternative vehicles replacements can result in huge impacts on fuel consumption, fuel costs and consequently on environment. 
Table 5: Environmental impact of alternative vehicles compared with conventional vehicles based on range $100.000 \mathrm{~km}$, method Eco-indicator 99

\begin{tabular}{|c|c|c|c|c|}
\hline Vehicle & $\begin{array}{c}\text { Total environmental } \\
\text { impacts (Pt) }\end{array}$ & $\begin{array}{c}\text { Impacts on human } \\
\text { health (Pt) }\end{array}$ & $\begin{array}{c}\text { Impacts on quality } \\
\text { of ecosystem (Pt) }\end{array}$ & $\begin{array}{c}\text { Impact on } \\
\text { sources (Pt) }\end{array}$ \\
\hline $\begin{array}{c}\text { Vehicle with gasoline } \\
\text { engine (EURO 5) }\end{array}$ & 863 & 821 & 18.6 & 22.6 \\
\hline \hline $\begin{array}{c}\text { Vehicle with diesel } \\
\text { engine }\end{array}$ & 772 & 737 & 19.3 & 15.7 \\
\hline \hline Electric vehicle & 374 & 150 & 4.1 & 220,0 \\
\hline $\begin{array}{c}\text { Hybridni vehicle } \\
\text { (gasoline, electricity) }\end{array}$ & 716.3 & 619.7 & 14.2 & 81.8 \\
\hline Vehicle on gas power & 709 & 675 & 19.2 & 14,5 \\
\hline
\end{tabular}

Second fact is that fuel consumption is very high and consequently this causes high fuel costs in companies. Reason for high fuel consumption is usually in use of older vehicles. In project of greening the fleet in company Avtosteklo Ltd. participation and support of the top management was on high level, which resulted in high amount of data of existing fleet gathered in company. Top management is very interested in greening the fleet because of reduction of fuel costs and in improving their public image. We did our best to form solutions not only environmentally kind but also suitable to the company's activities as well as to their possibilities of financing. The main goal of reducing emissions of $\mathrm{CO} 2$ was accomplished, although we didn't set any values. Another goal was met in this study: to prove that replacement of conventional vehicles with alternative ones results in significant reduction of emissions. The most consuming part of the study was calculating amounts of fuel consumption and emissions produced. Second challenge was to find alternative solutions which would meet goals set and on the other hand all standards suitable for company. We evaluated all vehicles in existing fleet as significant for the company's activities that is why we did not eliminated any of those. Optimization of travel routes wasn't done, because the company already successfully optimizes it, as well as regular maintenance of fleet's vehicles. Suggested alternative vehicles were carefully selected in order to meet all company's needs, reduce fuel consumption and $\mathrm{CO} 2$ emissions, as well having in mind not to put too much financial burden on company. Purchase of alternative vehicles still may be huge investment, so we suggested few cheaper short term solutions, for the period before replacing the vehicles, until within few years total change of the fleet is done. Replacement with electric vehicles was suggested as long term project.

\section{REFERENCES}

1) Drumheller, B. Green your fleet, Available on: http://cec-mi.org/wp-content/uploads/2014/05/ Green-Your-Fleet-How-to-Adopt-a-Comprehensive-Green-Fleet-Policy.pdf, retrieved on June $25^{\text {th }}$, 2015.

2) FCM, (2010) Enviro-fleets: reducing emissions from municipal heavy-duty vehicles, Available on: https://www.fcm.ca/Documents/reports/Reducing_emissions_from_municipal_heavy_duty_vehicle_EN.pdf, retrieved on June $20^{\text {th }}, 2015$.

3) Graham, R. How to green the fleet, Available on: http://www.greenfleet.net/features/8-/1160-howto-green-the-fleet, retrieved on July $5^{\text {th }}, 2015$.

4) Katalog, Available on http://www.volvocars. $\mathrm{com} / \mathrm{si} /$ nakup/pregled/katalog, retrieved on June $29^{\text {th }}, 2015$.

5) Katalogi in ceniki, Available on http://ford.si/ Katalogi_In_Ceniki/Osebna_Vozila, retrieved on June $27^{\text {th }}, 2015$.

6) Knez, M., Obrecht, M., Sinko, S., Jež, S., Fras, Doroteja, Kovacheva, S., Koprivc, R., Leva, M. (2015) Ozelenitev voznega parka v podjetju Avtosteklo d.o.o. - final report, Celje: Faculty of Logistics University of Maribor (in Slovenian language only).

7) Lahka gospodarska vozila Renault, Available on https://www.renault.si/vozila/lahka-gospodarskavozila.html, retrieved on June $27^{\text {th }}, 2015$.

8) Majaron, T. M. (2009) "Izpusti toplogrednih plinov," Available on: http://kazalci.arso.gov. si/?data=indicator\&ind_id $=157$, retrieved on Maj $15^{\text {th }}, 2015$.

9) Modeli, Available on http://www.skoda.si/modeli, retrieved on June $28^{\text {th }}, 2015$.

10) Murray, J. (2007) "Green Company Cars Can Slash Firms' Fleet Costs," Available on: https:// www.greenbiz.com/news/2007/12/12/greencompany-cars-can-slash-firms-fleet-costs, retrieved on July $4^{\text {th }}, 2015$.

Paper sent to revision: 24.10.2016.

Paper ready for publication: 19.12.2016. 